inseparable from Pilgrim's ${ }^{13}$ Oioceros(?) grangeri from the Tung Gur Miocene, Mongolia. Pavlovič and Thenius ${ }^{14}$ mention a similar form from Yugoslavia. Oioceros(?) limb bones at Fort Ternan show more cursorial adaptations than Protragocerus. These two species constitute about 90 per cent of the recognizable Bovid remains at Fort Ternan. Also present is a species agreeing closely with a frontlet from the Nagri gen. indet. (cf. Tragoreas) potwaricus ${ }^{15}$. The fourth species is a Gazella with mediolaterally compressed horn cores, rather brachyodont cheek teeth and long premolars. The relative smallness of the Fort Ternan antelopes, vestigial alveoli for upper canines in Protragocerus, the resemblance of the Oioceros( ?) to the Tung Gur species, and the brachyodonty of the gazelle give them a more archaic aspect than those of Samos. What is most interesting is their relationship at the generic and higher levels to Eurasiatic forms, but not, apparently, to the later antelopes characteristic of Africa.

The presence of Boselaphini and Caprini in the late Miocene of equatorial East Africa upsets the strictly geographical part of the concept of Eurasiatic and African divisions of the Bovidae. We must evidently allow for past fluctuations of faunal boundaries, and, following Wells ${ }^{5}$, can refer to such divisions as "essentially Eurasiatic" and "essentially African". Only in the Tatrot and Pinjor of the Siwaliks is any mixing of the divisions known, apart from that along the wide boundaries of the Palaearctic and Ethiopian realms. Unanswered questions include: Where did the essentially African Bovidae evolve? Why are they absent from Fort Ternan but not from the later Pliocene and early Pleistocene of the Siwaliks? Could more mixing of the divisions be found from further excavations or from further studies of puzzling fossils?

Centre for Prehistory and Palaeontology

Nairobi, Kenya.

Received January 1; revised January 23, 1968.

1 Leakey, L. S. B., Ann. Mag. Nat. Hist.. 4 (13), 689 (1961).

2 Simpson, G. G, Bull. Amer. Mus, Nat, Hist, 85, 157 (1945).

3 Pilgrim, G. E., Palaeont. Indica (n.s.), 26, No. 1, 44, 130 (1939).

- Pilgrim, G. E., and Schaub, S., Abh. Schweiz. Paläont. Ges., 62, No. 3, 20 (1939)

'Wells, L. H., S. Afr. J. Sci., 53, 423 (1957).

' Pilgrim, G. E., Palaeont. Indica (n.8.), 26, No. 1, 63, 71, 93 (1939).

7 Gentry, A. W. Bull. Brit. Mus. Nat. Hist. (Geol.), 14, 296 (1967).

- Bohlin, B., Palaeont. Sin. C., 9, No. 4, 126, 130, 133 (1935).

- Schlosser, M., Beitr. Paläont. Geol. Öst.-Ung., 17, 34 (1904).

${ }^{10}$ Pilgrim, G. E., Palaeont. Indica (n.8.), 26, No. 1, 90, 119, 122, 125, 130 (1939).

11 Pilgrim, G. E., Bull. Amer, Mus, Nat, Hist, 72, 758 (1937).

12 Thenius, E., Geologie, 5, 315 (1956).

13 Pilgrim, G. E., Amer. Mus. Novit, No. 716, 4 (1934).

14 Pavlovic, M., and Thenius, E., Anz. Üt. Akad. Wiss, No. 11, 3 (1959).

${ }_{16}$ Pilgrim, G. E., Palaeont. Indica (n.8.), 26, No. 1, 86 (1939).

\section{Saprolegnia parasitica Coker in Estuaries}

IN a recent article Stuart and Fuller ${ }^{1}$ question whether Saprolegnia parasitica Coker should be regarded as a freshwater fungus or a fungus capable of growing and sporing in both freshwater and estuarine environments. I find that their review of data concerning the tolerance of Saprolegniaceae to saline environments is misleading because $(a)$ they fail to point out the discrepancy in the literature between the influence of temperature on spore production in the freshwater and saline environments, and $(b)$ they do not distinguish between vegetative growth with asexual sporulation and the mere presence of viable but unidentified propagules.

Some Saprolegniaceae such as Leptolegnia baltica Höhnk and Vallin ${ }^{2}$ appear to be adapted to life in slightly saline $(4-6 \%)$ conditions. Te Strake ${ }^{3}$ states that the
Saprolegniaceae which she isolated from estuarine water of salinity up to $2 \cdot 8 \%$ would tolerate greater salinities in vegetative culture at higher temperatures, but that asexual sporulation occurred in the higher salinities only at temperatures above $20^{\circ} \mathrm{C}$. At $15^{\circ} \mathrm{C}$ sporulation did not occur above a salinity level of $0 \cdot 3 \%$. The temperature data for asexual sporulation quoted by Stuart and Fuller refer to freshwater environments and may not, therefore, be relevant.

It is unfortunate that in their pure culture experiments Stuart and Fuller did not use fungi freshly isolated from their fish or the estuaries where they were working, and that they failed to give the temperature at which their experiments were carried out. (What is the maximum water temperature of, for example, the Shannon estuary ?)

Te Strake's work shows that viable propagules, which are not identified, are present in estuarine sites. The presence of propagules in moving water does not necessarily indicate their site of production. This applies to spores of Oomycetes just as much as to spores of Fungi Imperfecti1,4. Until the site of production is established comments on "habitat nomenclature" have no foundation $^{5}$.

To demonstrate that Saprolegnia parasitica is not confined to the freshwater environment for vegetative growth and the production of zoospores, it is essential to answer the following questions. (1) Does the fungus sporulate equally well in freshwater and estuarine water at temperatures and salinity values comparable with those in the natural environments under investigation? (2) Do the zoospores remain motile for the same length of time in both environments ? (3) How long do the motile or encysted zoospores remain viable in freshwater and estuarine water? (4) Will oospores germinate equally well in both environments? (5) Is the colonization of the substrate (living or dead) comparable in both environments? (6) What is the computed propagule density required to cause disease in particular hosts in a given environment (river, estuary or the open sea)?

If this fungus should prove to be a primary parasite rather than a facultative wound parasite, is it not more important to establish the origin and size of the potential spore inoculum and the survival rate of the inoculum in saline conditions, rather than the vegetative growth of the fungus in saline media at unspecified temperatures?

Department of Botany,

University of Reading.

M. W. Dick

Received February 2, 1968.

${ }^{2}$ Stuart, M. R., and Fuller, H. T., Nature, 217, 90 (1968).

'Höhnk, W., and Vallin, S., Veröff. Inst. Meeresforsch. Bremerh., 2, 215 (1963).

3 Te Strake, D., Phyton, Intern. J. Exp. Bot., 12, 147 (1959).

- Willoughby, L. G., J. Ecol., 50, 733 (1962).

${ }^{5}$ Dick, M. W., Veröff. Inst. Meeresforsch. Bremerh., Sonderband 3 (in the press).

\section{Chlamydomonas: Adaptation Phenomena in Phototaxis}

THE oriented movement of unicellular algae, such as Chlamydomonas, is usually regarded as being either positive or negative, when evoked by light of a fixed intensity. Until recently it has been difficult to measure phototactic responses of algae quantitatively and rapidly, but methods have now been described for following the phototactic response of a population of algae ${ }^{1,2}$. These methods are based on a photoelectric monitoring of the distribution of the algae in a suspension, during exposure to light which evokes oriented response. We have adopted the method of Feinleib and Curry ${ }^{2}$ essentially unmodified to follow the initial response of cultures of Chlamydomonas reinhardii $(W T+2)$. The experiments were undertaken to study the variability of the photo. 